\title{
AKULTURASI ISLAM SUNDA \\ (Kajian terhadap Tradisi Hajat Sasih)
}

\section{Abdurrahman Misno Bambang Prawiro}

\author{
STAI Al-Hidayah Bogor \\ Jl. Raya Dramaga Raya KM 6, Bogor \\ E-mail: ambp1979@yahoo.com \\ HP. +6285885753838
}

Abstract: This research is about Idul Adha festival which is combined with Hajat Sasih, a ritual that is spread out in Kampung Naga. Phenomenological approach with ethno science paradigm by James P. Spradley is used to record the festival. It has been found that the festival is without slaughtering the livestock and the Hajat Sasih ritual is dominated the festival. Hajat Sasih is a kind of thankfulness to God by visiting the cemetery of the ancestors; Sembah Dalem Eyang Singaparana besides it is also a special moment for the people to get the benefit of silaturahmi, ziarah kubur and tumpeng which are blessed by the senior villager. The people are presenting a gift to religious leaders and village leaders.

Abstrak: Perayaan Hari Raya Idul Adha di masyarakat adat Kampung Naga sangat menarik karena dilanjutkan dengan ritual Hajat Sasih sebagai bentuk ungkapan terima kasih kepada nenek moyang. Penelitian ini menggunakan pendekatan fenomenologi dengan paradigma etnoscience dari Spradley, yang direkam dengan metode etnografi. Hasil dari penelitian ini adalah bahwa pelaksanaan Perayaan Idul Adha dilaksanakan dengan penuh khidmat sesuai dengan ajaran Islam, walaupun tidak ada penyembelihan domba. Sikap menghormati adat daripada perayaan Idul Adha menjadikan mereka lebih mengutamakan ritual adat dalam bentuk Hajat Sasih daripada Idul Adha yang sunah hukumnya. Ritual Hajat Sasih dilaksanakan setelah shalat Idul Adha, dengan memberikan Pahajat (bingkisan berisi makanan dan hasil bumi). Hajat Sasih merupakan ungkapan rasa syukur kepada Tuhan yang direpresentasikan dalam bentuk ziarah ke makam leluhur. Selain itu, Hajat Sasih juga menjadi momen istimewa bagi warga Kampung Naga untuk bersilaturahmi dan mengharapkan berkah dari ziarah kubur dan dari tumpeng yang didoakan oleh sesepuh Kampung Naga.

Kata Kunci: Islam Lokal, Hari Raya Idul Adha, Hajat Sasih, Kampung Naga, Ziarah. 


\section{A. Pendahuluan}

Setelah manusia memahami bahwa agama adalah bagian dari kebutuhan hidupnya, selanjutnya mereka mencoba untuk mengaplikasikan keyakinan tersebut dalam berbagai pola dan ritual keagamaan. Saat ini, manusia berusaha untuk mendekatkan diri kepada Tuhan dengan berbagai ritual keagamaan yang mereka yakini mampu menjadi wasīlah bagi kedekatannya dengan Tuhan. Walaupun ada banyak ritual keagamaan yang dilakukan oleh manusia, namun semuanya memiliki mata rantai yang tidak bisa diputus dan terlihat dari esensi ritual keagamaan tersebut. Semua itu dilakukan dalam upaya untuk mendekatkan diri kepada Tuhan. Mereka meyakini bahwa ritual tersebut akan menjadi satu jalan bagi kebahagiaan dan kedamaian dalam kehidupan.

Di antara bentuk ritual keagamaan yang telah ada sejak dahulu adalah penghormatan terhadap nenek moyang. Ritual ini adalah salah satu dari ritual khas dari berbagai suku bangsa yang ada di Indonesia, dari ujung barat Indonesia di Aceh hingga ujung timur Indonesia di Merauke. Mereka memiliki ritual keagamaan dalam bentuk penghormatan kepada nenek moyang. Ketika nenek moyang tersebut sudah meninggal dunia, ritual penghormat an tersebut diarahkan ke makam atau kuburan nenek moyang tersebut. Dari sinilah muncul ritual untuk menghormati leluhur, dalam taraf lebih lanjut adalah muncul keyakinan bahwa arwah nenek moyang itu memiliki kekuatan yang dapat memengaruhi kehidupan manusia (animisme).

Suku Sunda sebagai salah satu dari suku bangsa yang ada di Indonesia juga memiliki ritual untuk menghormati para leluhurnya. Hal ini terlihat dari berbagai ritual keagamaan yang ada di wilayah yang didiami oleh suku Sunda, terutama di Provinsi Jawa Barat, Banten, sebagian Jawa Tengah dan DKI Jakarta. Di Panjalu Kabupaten Ciamis terdapat ritual Nyangku yaitu ritual yang dilakukan sebagai bentuk penghormatan kepada leluhur dari Kerajaan Galuh Panjalu. Di Kabupaten Garut ada ritual Ziarah Makam Karamah, yaitu mengunjungi makam leluhur Kampung Dukuh agar keinginannya dapat tercapai. Di Kabupaten Bogor dan Kuningan ada Seren Taun Guru Bumi sebagai bentuk syukur kepada Tuhan, ritual ini diawali dengan ziarah ke beberapa makam leluhur. Di Propinsi Banten ada komunitas Badui yang memiliki ritual Muja yaitu penghormatan kepada situs leluhur (Ekadjati, 2009: 63). Demikian pula di Indramayu terdapat ritual Sedekah Bumi sebagai bentuk rasa syukur kepada Tuhan dengan mengunjungi makam leluhur. Di Kampung Adat Banceu Kabupaten Subang terdapat ritual Ngaruat Bumi sebagai bentuk penghormatan kepada leluhur mereka. Demikian pula di Tasikmalaya ada Hajat Sasih yang dilaksana- 
kan oleh masyarakat Kampung Naga sebagai sebuah ritual untuk menghormati leluhur Kampung Naga.

Ketika Islam datang ke tanah Pasundan dan bersentuhan dengan budaya Sunda terjadilah dialog di antara keduanya, terjadi proses saling mengisi dan melengkapi antara Islam dan budaya Sunda, sehingga terciptalah satu kebudayaan yang merepresentasikan kedua kebudayaan tersebut. Kebudayaan baru ini kemudian diwariskan secara turun temurun sehingga sadar atau tidak kebudayaan baru tersebut merupakan budaya Islam dengan citarasa lokal. Di antara wujud dari dialog antara Islam dan budaya lokal adalah perayaan hari raya Idul Adha yang dilanjutkan dengan ritual Hajat Sasih yang dilaksanakan oleh masyarakat Kampung Naga di Kabupaten Tasikmalaya. Masyarakat Kampung Naga sebagai sub-kultur budaya Sunda menerima Islam sebagai agamanya sejak pembukaan awal Kampung Naga sehingga proses akulturasi tersebut tidak disadari oleh generasi sesudahnya. Tulisan ini akan membahas proses pelaksanaan Hajat Sasih di Kampung Naga dan proses akulturasi Islam dan adat Sunda.

\section{B. Sistem Religi}

Masyarakat Kampung Naga seluruhnya beragama Islam, sejak awal pembangunannya Islam telah menjadi agama leluhur mereka. Bukti akan hal ini adalah sebuah lokasi bekas tempat shalat yang hingga saat ini dilestarikan dengan sebutan Peshalatan atau Depok. Pada saat pelaksanaan Hajat Sasih, tempat ini dibersihkan sebagai bentuk penghormatan kepada para leluhur yang telah membangun tempat tersebut. Keislaman mereka juga tercermin dalam kehidupan sehari-hari, mereka melaksanakan shalat lima waktu, mengumandangkan adzan dan melaksanakan shalat berjamaah di masjid. Masjid Kampung Naga yang berada di tengah-tengah pemukiman menjadi pusat kegiatan keagamaan masyarakat. Ia menjadi tempat pelaksanaan hari-hari besar Islam seperti shalat Idul Adha, Shalat Idul Fitri, Mauludan, Nisfu Sya'ban, Shalat Tarawih di bulan Ramadhan, dan shalat Jumat. Pelaksanaan shalat Jumat dilakukan dengan khatib berasal dari pengurus masjid dan bergantian dengan beberapa warga yang dianggap mampu menjadi khatib Jumat. Masjid juga menjadi pusat kegiatan dalam pelaksanaan Hajat Sasih yang dilaksanakan sebanyak enam kali dalam satu tahun. Pada hari-hari biasa masjid dijadikan tempat untuk mengaji al-Qur'an bagi anak-anak masyarakat Kampung Naga.

Pelaksanaan agama Islam di Kampung Naga tidak menghilangkan tradisi dan adat-istiadat yang mereka terima secara turun-temurun dari para leluhurnya. Keyakinan-keyakinan mengenai berbagai hal gaib masih mereka 
yakini sebagai suatu ketetapan yang harus diyakini. Demikian juga ketika ada perintah yang berasal dari leluhur, maka mereka akan segera melaksanakannya. Jika itu suatu larangan maka mereka sekali-kali tidak akan pernah berani melanggarnya. Beberapa aturan adat yang masih bertahan hingga kini misalnya mengenai larangan memasuki Hutan Larangan, makam Sembah Dalem Eyang Singaparana, Bumi Ageung, dan hutan keramat. Tempat-tempat tersebut menurut keyakinan mereka adalah tempat suci yang tidak boleh sembarang orang memasukinya. Selain itu, bagi yang duduk atau tidur dilarang untuk menjulurkan kakinya ke arah barat. Berbagai larangan ini mereka sebut dengan "pamali" yaitu at uran yang tidak tertulis, namun sudah dipahami oleh seluruh masyarakat Kampung Naga.

Dalam hal keyakinan, masyarakat Kampung Naga juga masih meyakini adanya berbagai makhluk halus yang menguasai beberapa tempat di sekitar kampung. Misalnya, adanya penunggu air yang disebut jurig cai, kuntilanak, dan lain sebagainya. Sebagai masyarakat agraris, mereka juga mengenal tokoh dewi padi yang disebut Nyi Pohaci. Bentuk penghormatan pada Nyi Pohaci dilakukan dengan berbagai aturan-aturan yang berkaitan dengan padi, misalnya menyediakan rujakan dalam setiap tahap pertumbuhan padi di sawah hingga proses penyimpanan di leuit. Selain itu, sebagaimana masyarakat adat pada umumnya, maka mereka sangat menghormati leluhurnya. Oleh karena itu, untuk mengenang kembali dan menghormati para leluhur dilaksanakanlah ritual dalam bentuk berziarah ke makam leluhur. Di Kampung Naga, ritual untuk melakukan ziarah ke makam para leluhur disebut Hajat Sasih yang dilaksanakan enam kali dalam satu tahun (Aziz, 2002: 7-10).

Untuk menjaga kelestarian adat-istiadat Kampung Naga, maka warga masyarakat memiliki pantangan untuk membicarakan hal-hal yang berkenaan dengan adat mereka, yaitu pada hari Selasa, Rabu dan Sabtu. Pada ketiga hari ini mereka tidak diperbolehkan untuk membicarakan masalah adat, ketiga hari tersebut digunakan untuk merenung, introspeksi diri dan upaya untuk dapat melaksanakan adat para leluhur dengan lebih baik. Pada ketiga hari ini tidak ada perayaan atau amalan-amalan khusus, hanya saja ketiga hari ini memiliki kedudukan yang sangat penting sehingga segala acara apapun akan ditunda atau dialihkan ke hari lain jika bertepatan dengan ketiga hari tersebut.

\section{Perayaan Idul Adha dan Ritual Hajat $S_{a s i H}$}

Suasana masjid tampak temaram dengan lampu minyak tanah di bagian tengah, seorang lelaki tengah mengumandangkan adzan dengan sebelumnya memukul kokol dan bedug pertanda waktu Subuh telah tiba. Hanya selang 
beberapa menit untuk melaksanakan shalat sunah Subuh iqamat-pun dikumandangkan. Selaku imam shalat Subuh, Bapak Karmadi salah seorang warga Kampung Naga yang juga merupakan keluarga dekat Kuncen Kampung Naga. Beberapa lelaki berbaris di belakangnya menjadi makmum, tidak lebih dari sepuluh orang peserta shalat Subuh berjamaah pada Subuh ini. Setelah berdzikir sejenak masing-masing mereka bersalaman dan segera menuju ke rumah masing-masing. Kang Entang sendiri kembali ke rumah sebentar mengganti pakaian shalatnya lalu segera menuju ke balong (Unggara, 2012: ii).

Setelah ditinggal kurang lebih 1,5 jam, air dalam balong tersebut sudah surut, ikan-ikan yang sebelumnya tidak tampak kini mulai terlihat menggelepar mencari air yang lebih dalam. Setelah menunggu sebentar, akhirnya Kang Entang turun dan membuat semacam parit kecil untuk memudahkan penangkapan ikan. Setelah melakukan beberapa gerakan agar ikan-ikan tersebut berkumpul di tempat yang telah disediakan segera ia membendung tempat tersebut dan mulai menangkap ikan-ikan tersebut dengan bantuan sair. Kang Entang tidak sendirian, ia kini dibantu oleh beberapa warga yang datang untuk membantu menangkap ikan tersebut. Ada Pak Ucu, Kang Iin, dan tidak ketinggalan anaknya pun ikut turun ke balong.

Sesuai dengan permintaan dari tetua adat, maka ikan yang pertama kali diambil adalah ikan Nila. Dengan bantuan sair, Kang Entang menangkap beberapa ekor ikan Nila dan dimasukkan ke dalam tempat dari bekas jerigen yang dibelah bagian pinggirnya. Setelah ditimbang ternyata mencapai $20 \mathrm{~kg}$ ikan Nila, lalu ikan tersebut segera dibawa ke rumah tetua adat untuk dimasak. Selanjutnya, ikan yang ditangkap adalah ikan Nilem. Oleh karena ikan ini tersedia dalam jumlah banyak, maka dilakukan seleksi, yaitu dengan memilih ikan Nilem yang benar-benar telah siap dipanen untuk Hajat Sasih. Pada Hajat Sasih kali ini, ikan Nilem yang ditangkap seberat $25 \mathrm{~kg}$ yang dibagikan kepada warga terutama para sesepuh adat. Satu hari sebelum Hajat Sasih, digunakan oleh warga Kampung Naga untuk menyiapkan hidangan yang akan digunakan pada ritual tersebut. Beberapa ibu terlihat sibuk menumbuk beras untuk dijadikan tepung sebagai bahan pembuatan gorengan, sementara sebagian lainnya menumbuk padi menjadi beras untuk keperluan yang sama. Beberapa warga yang menggunakan beras dengan jumlah yang banyak memilih menggiling padi dengan mesin penggiling padi atau ngadisel (Ningrum, 2012: 49).

Para lelaki di Kampung Naga juga tidak tinggal diam, sebagian mereka sibuk dalam persiapan Hajat Sasih esok hari. Jika ikan Nilem diperoleh dari balong umum, maka sebagian warga juga memancing di balong milik mereka sendiri. Sementara itu, sebagian yang lain memancing di sungai Ciwulan. Bagi 
yang tidak suka dengan ikan, mereka memilih ayam sebagai hidangan Hajat Sasih. Daging ayam tersebut sebagian diperoleh dengan membeli di luar, sedangkan sebagian yang lain memotong ayam yang menjadi ternak peliharaan mereka yang disebut hayam kolong. Bagi yang ingin praktis, mereka memilih lauk-pauknya dengan membeli di warung yang berlokasi di luar kampung atau menunggu para pedagang yang berkeliling ke Kampung Naga, misalnya membeli tempe, tahu, dan lauk-pauk lainnya.

Persiapan Hajat Sasih semakin terasa ketika matahari mulai merangkak ke angkasa, ibu-ibu yang tadi pagi sibuk dengan pekerjaan rumah tangganya kini mulai beralih ke pekerjaan dua bulanan yaitu menyiapkan hidangan untuk Hajat Sasih esok hari. Persiapan satu hari sebelum acara adalah menyiapkan lauk yang tidak bisa dimasak secara mendadak misalnya ikan goreng, ayam goreng atau mengupas kentang. Tentu saja, sebelum acara masak-memasak dimulai terlebih dahulu peralatan masak tersebut dibersihkan dan dipersiapkan. Pekerjaan membuat tumpeng menjadi hal utama dalam mempersiapkan Hajat Sasih bagi ibu-ibu, maka hal yang harus ada adalah daon cau (daun pisang) sebagi alas sekaligus penutup tumpeng. Maka untuk urusan ini menjadi tanggung jawab para lelaki untuk mencari daon cau tersebut.

Satu hari menjelang Hajat Sasih juga dilakukan pahajat yaitu mengantar atahan kepada Punduh dan Lebe. Atahan sendiri adalah hasil bumi semisal, beras, pisang, singkong, ubi dan lain sebagainya sebagai bentuk penghormatan kepada para sesepuh Kampung Naga. Tradisi memberikan hajatan ini secara turn-temurun dilaksanakan sesuai dengan yang dilakukan oleh nenek moyang mereka. Dalam hal ini jika satu keluarga memberikan pahajat-nya kepada seorang Punduh maka secara turun-temurun atahan tersebut akan diberikan kepada Punduh setiap akan dilaksanakan Hajat Sasih. Demikian juga jika sebuah keluarga memberikan pahajat-nya kepada Lebe maka anak turunannya juga akan memberikan pahajat tersebut kepada Lebe. Atahan yang diberikan oleh warga kepada Punduh dan Lebe akan dimanfaatkan untuk keperluan warga terutama pada saat Hajat Sasih ataupun malam-malam takbiran ketika Hajat Sasih tersebut dilaksanakan pada bulan Syawwal, Rayagung (Idul Adha), dan Mulud.

Punduh dan Lebe sendiri mempunyai tradisi untuk memberikan Pahajat kepada Pak Kuwu (Kepala Desa) dan Pak Naib. Punduh akan selalu memberikan Pahajat-nya kepada pak Kuwu (Kepala Desa) sementara Lebe akan memberikan Pahajat-nya kepada Pak Naib. Tidak jauh berbeda dengan pahajat yang diberikan oleh warga kepada Puduh dan Lebe, maka pahajat keduanya juga berupa beras, pisang, ubi, singkong dan hasil kebun lainnya. Selain itu, dibawakan 
juga seekor ayam yang masih hidup sebagai pelengkapnya. Kebiasan memberikan pahajat kepada kuwu dan naib adalah sebagai bentuk penghormatan sekaligus ucapan terima kasih sebagai warga desa kepada para pemimpin pemerintahan formal.

Dari wawancara yang dilakukan dengan Punduh Kampung Naga, diketahui bahwa sesungguhnya salah satu dari inti Hajat Sasih adalah memberikan pahajat kepada para sesepuh dan pimpinan, baik yang formal (Kuwu dan Naib) maupun non-formal (Punduh dan Lebe). Tujuannya adalah sebagai bentuk penghormatan dan ketaatan bagi warga kampung bagi para sesepuh yang telah mengayomi mereka. Kegiat an menyerahkan pahajat dilakukan secara sukarela, dalam hal ini bukanlah sesuatu yang diwajibkan sehingga ada beberapa keluarga yang tidak memberikan pahajat-nya. Pemberian pahajat sendiri dilakukan sejak beberapa hari sebelum pelaksanaan Hajat Sasih dan maksimal satu hari sebelum pelaksanaan. Tradisi ini dilakukan secara turuntemurun sejak zaman dahulu kala sehingga warga akan merasa malu ketika tidak melaksanakannya.

Sebagai persiapan Hajat Sasih juga, sebagian warga mengambil akar pohon Kapirit untuk kuramas dan bebersih. Fungsinya adalah semacam sampo yang digunakan pada saat Hajat Sasih, terutama pada saat mandi di sungai Ciwulan. Akar ini diambil dari nagawir lereng-lereng di tepian sungai Ciwulan dan beberapa lokasi lainnya. Nantinya akar ini akan dicampur dengan buah Honje sebagai sampo tradisional. Pelaksanaan Hajat Sasih kali ini agak berbeda karena bersamaan dengan perayaan Hari Raya Idul Adha. Sebagaimana umat Islam lainnya, masyarakat Kampung Naga juga merayakan Idul Adha ini. Ciri khas dari perayaan Idul Adha di Kampung Naga adalah pelaksanaan takbiran pada malam harinya.

Ketika matahari telah kembali ke peraduannya, kumandang adzan terdengar dari masjid yang berada di tengah kampung. Walaupun tanpa speaker atau pengeras suara, namun panggilan menuju kemenangan itu sayup-sayup memasuki setiap jengkal Kampung Naga. Beberapa laki-laki tampak bergegas dengan memakai sinjang (sarung) dan tidak lupa ikat kepala. Shalat maghrib secara berjamaah dilaksanakan dengan imam Kang Iin sebagai wakil dari DKM masjid. Suasana masjid sedikit berbeda dengan hari-hari biasa. Jika pada hari biasa penerangan masjid hanya menggunaan lampu minyak, maka pada malam ini penerangan berupa lampu petromak sehingga suasananya lebih terang dan lebih meriah dengan kehadiran anak-anak kampung.

Kesibukan di rumah warga juga sudah tampak, selain unt uk persiapan Hajat Sasih sebagian mereka juga menyiapkan hidangan istimewa untuk acara 
takbiran yang akan dilaksanakan malam ini untuk menyambut Hari raya Idul Adha esok hari. Istri Punduh Ma'un sibuk dengan memotong cabe hijau, kembang Honje (kecombrang), tempe dengan potongan dadu, serta sayur lainnya yang akan dijadikan masakan gembrung ${ }^{l}$ khas takbiran. Perempuan tua dengan badan yang tinggi semampai ini tidak sendirian, ia dibantu oleh anak perempuannya dan juga istri Lebe Ateng bersama-sama menyiapkan hidangan untuk takbiran Idul Adha.

Shalat Isya baru saja selesai ketika beberapa laki-laki warga Kampung Naga berdatangan ke masjid, sebagian mereka mengenakan baju kampret warna putih dan hitam, memakai sarung dan tidak lupa iket yang menempel di kepala mereka. Tanpa dikomando, beberapa lelaki mengambil terbang gembrung ${ }^{2}$ dari balik pengimaran ${ }^{3}$ setelah semua dikeluarkan satu persatu terbang tersebut diperbaiki oleh beberapa warga. Tampak Kuncen, Punduh dan Lebe duduk di bagian depan masjid, sementara warga yang sudah siap memegang terbang bergerombol di sebelah kanan. Tampak Kang Entang memegang terbang besar bersandar di barisan paling pinggir.

“Allāhu Akbar... Allāhu Akbar... Allāhu Akbar..." suara takbir dengan logat khas Sunda perlahan mengalun syahdu, suara terbang yang ditabuh dengan nada lambat mengiringi suara takbir yang terus mengalun dari warga yang datang. Beberapa anak Kampung Naga tampak bergerombol di bagian belakang masjdi dan tempat shalat perempuan. Suasana benar-benar khidmat hingga menjelang tengah malam, beberapa makanan khas kampung seperti pisang rebus, wajik, ubi rebus, kue pisang disajikan dengan menggunakan rigen besar. Kepulan asap dari para penabuh terbang dan warga yang hadirin menyajikan pemandangan khas kampung yang hanya ditemui setahun sekali pada Idul Adha. Waktu menunjukkan pukul 11.00 ketika waktu yang ditunggutunggu tiba, hidangan khas malam Idul Adha yaitu sayur gembrung tiba. Tanpa menunggu beberapa warga menyiapkan masakan tersebut, nasi dimasukkan ke dalam piring terbuat dari seng dibagikan satu per satu kepada seluruh warga

\footnotetext{
${ }^{1}$ Masakan Gembrung di Kampung Naga mirip dengan sayur lodeh di beberapa wilayah lain, bedanya sayur ini menggunakan campuran cabe hijau dalam jumlah banyak yang menjadikan rasanya pedas sehingga bermanfaat untuk mengusir rasa kantuk bagi para peserta takbiran. Menu ini ditambah dengan ikan Nilem goreng.

${ }^{2}$ Terbang Gembrung adalah sejenis rebana dengan ukuran besar, ia merupakan salah satu dari kesenian yang ada di Kampung Naga, terbang ini hanya dikeluarkan tiga kali dalam setahun, saat Idul Adha, Idul Fitri dan Maulud Nabi.

${ }^{3}$ Pengimaran adalah tempat bagi khatib untuk menyampaikan khutbahnya baik khutbah Jumat, Idul Fitri dan Idul Adha. Bagian bawah belakang pangimaran terdapat sebuah tempat yang digunakan untuk menyimpang terbang gembrung.
} 
yang hadir, dimulai dengan memberikannya kepada Kuncen, Punduh, Lebe, dan para pemuka adat. Semua tampak bergembira dan menikmati masakan tersebut, ini adalah awal dari sebuah perayaan yang akan dilaksanakan esok hari. "Menjadi sebuah amalan ibadah ketika bisa menghidupkan malam lebaran rayagung," kata Didin salah seorang warga Kampung Naga.

Waktu Subuh, menjelang pelaksanaan Shalat Idul Adha dan Hajat Sasih, tidak ada aktivitas yang berarti selain shalat Subuh dan bagi ibu-ibunya sejak bangun pagi tadi melanjutkan kegiatan menyiapkan tumpeng dan laukpauknya. Shalat Subuh berjama'ah di masjid Kampung Naga berlangsung seperti biasa, setelah memukul kokol dan bedug selanjutnya dikumandangkan adzan oleh muadzin. Shalat Subuh dilaksanakan dengan penuh khidmat di bawah temaram lampu minyak. Hanya ada beberapa lelaki yang mengikuti shalat Subuh berjama'ah di masjid, sebagian yang lainnya melaksanakannya di rumah.

Pukul 06.30, seluruh warga laki-laki bergegas mendatangi Masjid, suasana masih tampak lengang. Kabut tipis masih meliputi wilayah Kampung Naga, ketika shalat Idul Adha dimulai. Pak Danu bertindak sebagai Imam dan muadzin adalah Kang Iin, tiga orang perempuan warga tampak berada di bagian belakang masjid mengikuti jalannya Shalat Idul Adha, sementara yang lainnya sibuk menyiapkan tumpeng untuk Hajat Sasih. Setelah pelaksanaan shalat selesai dilanjutkan dengan khutbah Idul Adha yang disampaikan oleh Pak Danu, menggunakan baju koko warna putih, sarung kotak-kotak warna coklat serta Peci Hitam, khatib menyampaikan khutbahnya dengan menggunakan bahasa Arab dan sebagian Bahasa Sunda. Jamaah yang hadir di tempat itu tampak khidmat mendengarkannya, walaupun suasana di luar gerimis namun tidak menyurutkan kekhidmatan pelaksanaan perayaan Idul Adha.

Setelah shalat selesai, dilanjutkan dengan berjabat tangan kepada Kuncen, Punduh, Lebe, dan beberapa tetua adat. Kemudian masing-masing kembali ke rumah untuk mempersiapkan diri melaksanakan Hajat Sasih. Tidak ada pemotongan hewan kurban, baik sapi ataupun domba. Hasil wawancara dengan Kuncen Kampung Naga menyebutkan bahwa tidak adanya pemotongan hewan kurban bukan tanpa sebab. Warga kebanyakan memiliki penghasilan yang paspasan sehingga penghasilannya hanya cukup untuk makan, tidak ada untuk berkurban. Apabila dilihat dari satu sisi, maka alasan ini ada benarnya, sebagian besar warga Kampung Naga adalah petani yang memiliki penghasilan kecil. Namun, di balik itu, keyakinan bahwa adat lebih utama dilaksanakan daripada kurban tampak dari perayaan ngaruwat lembur yang memotong kambing sebagai sembelihan membuktikan kebalikan dari alasan pertama. Tidak adanya 
domba yang dijadikan kurban pada perayaan Idul Adha bukan tanpa sebab, namun ia adalah salah satu pola keagamaan masyarakat Kampung Naga yang lebih kuat memegang teguh adat-istiadat mereka.

Waktu menunjukkan pukul 09.00 WIB ketika terdengar suara Kokol (kentongan) dipukul oleh seorang warga, ini adalah tanda dimulainya pelaksanaan Hajat Sasih. Tanpa menunggu komando lainnya, para peserta Hajat Sasih segera menuju sungai Ciwulan. Beberapa dari mereka masih mengenakan pakaian lengkap, sementara sebagian yang lainnya hanya menggunakan kain sarung dengan bertelanjang dada. Kesamaan di antara mereka adalah sudah tidak mengenakan alas kaki. Tampak Kuncen dan beberapa orang membawa tempat kecil seperti baskom yang akan digunakan sebagai tempat leuleuran. Para peserta Hajat Sasih berjalan ke arah timur menuju sungai Ciwulan, setelah keluar dari batas kampung berupa jaga kandang mereka berbelok ke arah kiri, menyusuri tepi sungai dan menuju ke tempat yang bisa digunakan untuk bebersih dan kuramas (mandi bersama).

Sesampainya di tepi sungai, beberapa warga memetik buah Honje lalu masing-masing mereka membentuk semacam kelompok untuk menumbuk akar Kepirit dan buah Honje tersebut pada sebuah batu. Ada lima kelompok yang masing-masing menumbuk akar tersebut dan mencampurnya dengan buah Honje. Selanjutnya, mereka memasukkan campuran tersebut ke dalam sebuah tempat khusus. Sebelum memulai bebersih terlebih dahulu kunci memimpin doa sebagai niat dalam mandi. Selanjutnya, masing-masing peserta mengambil shampo tersebut dan mengusapkannya di kepala kemudian membilasnya dengan air sungai Ciwulan. Setelah kuramas selesai dilanjutkan dengan mandi seperti biasa dengan membuka seluruh pakaian dan berendam di sungai Ciwulan. Setelah selesai mandi, diteruskan dengan abdas (berwudhu) dan memakai sinjang (kain sarung). Setelah selesainya ritual ini, maka setiap peserta tidak diperbolehkan untuk memakai pakaian dalam dan alas kaki. Demikian juga setelah mandi tidak diperkenankan untuk menggunakan handuk. Tidak memerlukan waktu lama untuk melakukan ritual ini, tidak sampai setengah jam sudah selesai.

Selanjutnya masing-masing peserta kembali ke rumah masing-masing untuk mengganti pakaian. Pakaian yang digunakan untuk Hajat Sasih terdiri dari tiga buah, yaitu Totopong (ikat kepala), baju jubah, dan sinjang (kain sarung). Pakaian ini khusus hanya digunakan untuk acara Hajat Sasih yang dilaksanakan enam kali dalam satu tahun. Penggunaan totopong (ikat kepala) berbeda dengan ikat kepala yang digunakan sehari-hari. Demikian juga pemakaian sinjang yang mencapai setengah betis. Jubah yang digunakan tidak 
menggunakan kancing, hanya ada seutas tali untuk menutup dada mereka. Namun, dalam kenyataannya, tali ini jarang tidak digunakan. Para peserta membiarkan dadanya terbuka. Ikat pinggang juga digunakan berupa kain putih panjang yang digunakan untuk menguatkan sinjang. Mereka tidak diperbolehkan menggunakan alas kaki dan juga pakaian dalam.

Setelah selesai memakai pakaian selanjutnya para peserta Hajat Sasih menuju ke Masjid. Mereka masuk ke dalam masjid dengan rapi setelah terlebih dahulu mencuci kaki di tempat wudhu yang berada di sebelah kiri dan kanan masjid. Tujuan dari menunggu di masjid adalah menanti Kuncen, Punduh, dan Lebe yang sedang memohon izin ke Bumi Ageung. Kuncen, Punduh, dan Lebe berangkat menuju ke Bumi Ageung dengan membawa leumareun. Masingmasing mereka membawa leumareun milik mereka sendiri dan titipan dari warga Kampung Naga. Ritual di Bumi Ageung dilakukan oleh Kuncen sendiri, sementara Punduh dan Lebe menunggu di luar Bumi Ageung. Kuncen masuk ke dalam dan melantunkan doa-doa yang intinya berisi permohonan izin untuk melaksanakan ziarah ke makam. Setelah ritual di Bumi Ageung selesai, selanjutnya Kuncen, Punduh, dan Lebe berangkat menuju makam. Melihat sesepuh ini menuju makam maka peserta Hajat Sasih segera berjalan beriringan menuju makam di belakang Kuncen, Punduh dan Lebe.

Para peserta Hajat Sasih keluar dengan membawa sapu nyere (sapu lidi) yang diambil dari para-para masjid. Sapu ini terbuat dari lidi pohon Kawung yang dibersihkan dari daunnya dan diikat dalam satu ikatan. Sapu tersebut diletakkan di pundak sebelah kanan, selanjutnya mereka secara beriringan berjalan menuju makam. Dari masjid mereka berjalan melewati depan Bale Patemon lalu berbelok ke kanan melalui jalan menanjak berbatu dan berbelok lagi ke kiri lalu berjalan lurus ke arah selatan dan berbelok lagi ke arah barat menuju makam. Cara jalan mereka beriringan dan berbaris satu-satu, tidak ada kata-kata yang keluar dari peserta, semuanya tampak khidmat dan penuh kekhusyukan.

Ritual di makam dimulai dengan permohonan izin oleh Kuncen kepada Eyang Sembah Dalem. Di depan makam, dengan suara yang halus, Kuncen melakukan unjuk-unjuk, memberitahu bahwa Seuweu-siwi Naga (anak cucu keturunan Kampung Naga) telah berkumpul dan menyampaikan maksud serta tujuannya menyelenggarakan ritual Hajat Sasih. Unjuk-unjuk dilakukan Kuncen sambil menghadap ke sebelah barat, ke arah makam. Arah barat artinya menunjuk ke arah kiblat. Selain menyampaikan niat ziarah, Kuncen juga menyampaikan sembah hormat dan permohonan maaf jika seandainya terdapat adat istiadat yang terlupakan atau sudah dilanggar. 
Setelah selesai, selanjutnya seluruh peserta dipersilakan untuk mulai membersihkan makam. Mereka menyapu, mencabut rumput yang tumbuh di sekitar makam, memotong pohon-pohon liar yang tumbuh di areal makam, dan membuang seluruh sampah yang ada di area tersebut. Memakan waktu cukup lama untuk membersihkan makam tersebut. Setelah selesai, selanjutnya mereka ngagunduk (duduk bergerombol), sementara Kuncen memimpin doa-doa berupa tawasulan kepada Eyang Sembah Dalem. Usai doa diteruskan dengan sungkeman, masing-masing peserta melakukan sungkem kepada Kuncen dengan cara mencium tangannya dan mengucapkan kata-kata yang baik.

Sekitar lima orang dari peserta mendahului mereka kembali untuk membersihkan Depok, yaitu lokasi bekas tempat shalat (peshalatan) yang berada di belakang rumah Kuncen atau di bagian depan sebelah kanan masjid dan Bale Patemon. Depok ini dikelilingi oleh pagar bambu bersilang dan tidak ada pintunya, maka satu-satunya cara untuk masuk ke dalamnya adalah dengan menggunakan taroje (tangga). Ada dua tangga yang digunakan, yaitu tangga untuk naik dari bagian luar dan tangga untuk turun di bagian dalam. Proses membersihkan depok dilakukan dengan membersihkan seluruh sampah yang ada di dalamnya, mencabuti rumput, dan menebas pohon-pohon liar yang tumbuh di area tersebut. Proses membersihkan tempat ini sangat khidmat sehingga tidak ada satu suarapun yang keluar dari mereka. Setelah selesai membersihkan, selanjutnya mereka mendekat batu yang menjadi bekas pengimaran dan melakukan sungkem sebanyak lima-tujuh kali kemudian berdoa. Masingmasing peserta yang membersihkan depok melakukan hal yang sama, yaitu sungkem (menangkupkan kedua telapak tangan dan mengisyaratkan ke batu tersebut dan ke bagian mukanya. Hal ini dilakukan sebanyak beberapa kali.

Jam dinding di masjid Kampung Naga menunjukkan pukul 12.30 ketika pelaksanaan shalat Jumat selesai. Tanpa membuang-buang waktu, peserta Hajat Sasih segera berkumpul dengan duduk berkeliling masjid dengan formasi di bagian depan duduk dengan bersila Kuncen, Punduh, Lebe, dan keluarga dekat Kuncen. Kuncen yang akan memimpin doa juga diikuti oleh anak laki-lakinya yang baru berumur 12 tahun, sejak shalat Jumat tadi anak tersebut selalu diajak oleh Kuncen. Sementara itu, peserta lainnya duduk di bagian selatan, timur, utara, dan dua baris berada di tengah. Posisi duduk mereka berhadap-hadapan dengan tumpeng berada di tengahnya. Di depan Kuncen sendiri dan para sesepuh terdapat banyak tumpeng yang diletakkan di dalam rigen dan boboko.

Sebelum pelaksanaan ngadu'aan tumpeng dimulai, beberapa warga yang belum melakukan sungkem di makam kepada Kuncen diperkenankan melakukan sungkeman terlebih dahulu kepada Kuncen. Satu per satu mereka 
menuju Kuncen dengan penuh khidmat, menyalami Kuncen dan mencium tangannya. Tidak ada kata-kata yang terucap, setelah selesai mereka kembali ke tempat duduknya masing-masing.

Sementara itu, warga yang dari tadi membawa tumpeng dipersilakan untuk memasukkan tumpeng-tumpeng-nya ke dalam masjid. Warga yang didominasi oleh ibu-ibu segera berhamburan menuju ke dua pintu utama masjid untuk memasukkan tumpeng-nya. Selain it u, empat buah jendela yang berada di samping kiri kanan masjid juga digunakan untuk memasukkan tumpengtumpeng tersebut. Suasana cukup ramai ketika satu per satu ibu-ibu tersebut menyerahkan tumpeng ke peserta yang bertugas memasukkan tumpeng dari warga ke dalam masjid. Di bagian kanan masjid pada jendela bagian depan tampak Kang Entang sigap mengambil tumpeng dari warga Kampung Naga untuk diletakkan di dalam masjid. Semuanya tampak bergembira, dengan senyuman khasnya Kang Entang melayani mereka satu per satu. Sebagian warga ada yang masuk ke dalam masjid di bagian belakang untuk menyaksikan pelaksanaan doa ini, sementara sebagian lainnya menunggu di luar dengan duduk-duduk di sekitar masjid. Dari raut muka mereka terlihat khidmat menunggu selesainya pelaksanaan ngadu'aan tumpeng dalam rangkaian Hajat Sasih tersebut (Yandi, 2008: 5-17).

Setelah seluruh tumpeng masuk ke dalam masjid dan peserta Hajat Sasih telah siap, seorang perempuan yang disebut Patunggon menyerahkan leumareun kepada Kuncen sebagai bentuk pelayanannya kepada pemimpin mereka. Ngadu'aan tumpeng dimulai dengan membakar kemenyan dan Kuncen melafalkan doa-doa bagi keselamatan seluruh warga Kampung Naga dan Sa-naga. Dilanjutkan dengan ucapan salam dan nasihat-nasihat keagamaan bagi seluruh peserta Hajat Sasih. Sesekali tangan Kuncen dikatupkan secara bersamaan (sungkem) dengan meletakkan kedua ibu jarinya ke depan mulutnya. Setelah nasehat dari Kuncen selesai dilanjutkan dengan pembacaan doa oleh Lebe, seluruh peserta mengaminkan doa tersebut. Pada ritual Hajat Sasih yang dilaksanakan pada bulan mulud di akhir pembacaan doa masing-masing peserta memasukkan tangannya ke dalam tumpeng dan mengambil pucuk tumpeng tersebut dan meletakkannya pada lembaran daun pisang. Sambil terus berdoa, seluruh peserta memegang pucuk tumpeng tersebut.

Dengan selesainya pembacaan doa, maka berakhirlah Hajat Sasih, warga Kampung Naga dipersilakan untuk mengambil tumpeng-nya masing-masing. Agar tertib maka peserta Hajat Sasih yang bertugas di pinggir pintu dan dekat jendela membantu mengambilkan tumpeng-tumpeng tersebut dari dalam masjid ke warga secara estafet. Suasana sangat ramai dengan warga Sa-naga 
yang menunggu tumpeng-nya masing-masing. Satu per satu warga Kampung Naga mengambil tumpeng-nya dan membawanya pulang ke rumah, beberapa warga yang bertempat tinggal di luar Kampung berjalan beriringan keluar Kampung Naga dengan raut muka penuh kebahagiaan. Para peserta Hajat Sasih juga masing-masing mengambil tumpeng yang mereka bawa dari rumah, sebagian ada yang dimakan di rumah sementara sebagian lainnya dibawa pulang ke rumah. Kang Entang misalnya ia membawa tumpeng yang dibawanya dari rumah untuk dinikmati bersama keluarganya, "Ada keberkahan dalam tumpeng ini," begitu kata Pak Tatang, salah seorang warga Kampung Naga tersebut.

\section{Simpulan}

Tradisi Pahajat di Kampung Naga berupa pemberian hasil-hasil pertanian dan yang lainnya yang diberikan kepada para sesepuh, dalam hal ini adalah Lebe dan Punduh. Lebe dan Punduh sendiri akan memberikan pula Pahajat-nya kepada pejabat desa setempat yaitu Kuwu (kepala Desa) dan Naib. Tradisi dilakukan secara turun-temurun dan merupakan tradisi beberapa kerajaan di Indonesia. Dalam hal ini, disimpulkan bahwa tradisi Pahajat merupakan bentuk dari Adat dan Darigama (kewajiban taat kepada pemerintah).

Beberapa unsur adat yang ada adalah pemukulan kokol (Kentongan) di awal ritual. Kokol (Kentongan) sebagai alat musik tradisional Nusantara menjadi simbol bagi budaya lokal dalam hal ini adalah budaya Sunda. Selain sebagai alat musik sebenarnya kentongan berfungsi sebagai media komunikasi bagi warga masyarakat. Demikian juga ritual mandi di Sungai Ciwulan, tradisi ini terdapat di beberapa komunitas Adat, misalnya di Badui Kanekes Banten setiap diadakan upacara adat selalu didahului dengan bebersih badan terlebih dahulu. Di komunitas Cigugur Kuningan juga dilakukan sebagai tradisi awal dalam rangkaian ritual adat mereka. Dalam pelaksanaannya bebersih di sungai Ciwulan selalu dilanjutkan dengan ahdats yaitu membersihkan badan dari najis dan berwudhu, tentu saja ini adalah budaya Islam yang masuk ke dalam budaya lokal. Sementara itu, penggunaan akar Kapirit dan Honje sebagai alat pembersih merupakan kearifan lokal yang menjadi ciri khas dari Hajat Sasih di Kampung Naga.

Unjuk-unjuk di Bumi Ageung: Sebagai bentuk dari penghormatan kepada sesepuh maka dilakukan unjuk-unjuk ke Bumi Ageung. Tradisi ini berasal dari adat istiadat yang berasal dari penghormatan kepada nenek moyang. Hal ini didasarkan kepada keyakinan bahwa para leluhur memiliki hak untuk dimintai izin, terutama ketika akan melaksanakan Hajat Sasih. Tradisi berikutnya yaitu menyediakan leumaren yang merupakan budaya lokal sebagai bentuk peng- 
hormatan kepada para penunggu di suatu tempat atau juga bagi nenek moyang. Tradisi tawasul juga ada dalam Islam, yaitu menjadikan seseorang yang masih hidup, amal ibadah yang ikhlas ditujukan bagi Allah, bertawasul dengan namanama Allah ta' ala adalah tawasul yang diperkenankan dalam Islam. Dalam Hajat Sasih, tawasul dilakukan kepada penghuni makam yaitu Sembah Dalem Eyang Singaparna sebagai leluhur dan pendiri Kampung Naga.

\section{DAFTAR PUSTAKA}

Aziz, Abdul. 2002. Analisis Jaringan dalam Masyarakat Tradisional Kampung Naga: Kasus dalam Usaha Tani Padi. Bogor: Institut Pertanian Bogor.

Ekadjati, Edi S. 2009. Kebudayaan Sunda: Suatu Pendekatan Sejarah, Jilid 1. Jakarta: Pustaka Jaya.

Ningrum, Epon. 2012. "Dinamika Masyarakat Tradisional Kampung Naga di Kabupaten Tasikmalaya" dalam Mimbar Vol. XXVIII, No. 1, hlm. 4951.

Spradley, James P. 2007. Metode Etnografi. Yogyakarta: Tiara Wacana.

Unggara, Septian Restu. 2012. “Aktivitas Komunikasi Ritual dalam Upacara Hajat Sasih Kampung Naga Tasikmalaya”. Skripsi. Bandung: FISIP UKI.

Yandi, Harpat Ade. 2008. "Pelaksanaan Hukum Kewarisan di Lingkungan Adat Kampung Naga, Tasikmalaya”. Skripsi. Yogyakarta: UIN Sunan Kalijaga Yogyakarta. 